\title{
MEMORIES FROM PARIS: THREE PILGRIMAGES OF SERBIAN ARTISTS IN THE 1930s.
}

\author{
UDC 75.071.1(497.11)"19”
}

\author{
Ana Milošević \\ Indipendant researcher, Smederevska Palanka, Serbia
}

\begin{abstract}
The aim of this paper is to reveal some of the not so well known aspects about studying in Paris of the Serbian painters Ljubomir Ivanovic, Mihailo S. Petrov and Svetolik Lukic during the 1930s. A large number of painters travelled to Paris to learn about the contemporary trends in art, museums and galleries. Serbian/Yugoslav painters formed small colonies in Montparnase and Malakoffand, and they were actively involved in the bohemian art life.Those who could not afford to study or to live in Paris would go there for short "intensive" study trips that resembled pilgrimages. For a relatively short time they had to see all the wonders, visit the sites, absorb the atmosphere, history and culture of the French capital and to take home the impressions in their drawings and paintings. Ljubomir Ivanović, Mihailo S. Petrov and Svetolik Lukić among many faces of Paris chose to represent the identity of the city and their own identity.
\end{abstract}

Key words: Paris in 1930s, Ljubomir Ivanović, Mihailo S. Petrov, Svetolik Lukić, art pilgrimage.

During the Belle Époque (from the 1870s to the beginning of the World War I) and the time of peace, the widespread optimism and economic prosperity, Paris was the center of the artists from the whole world as it was the centre of contemporary artistic production, trade, and collecting (Argan \& Oliva 2005, 62). Montmartre and later Montparnasse were especially attractive since they were considered as places of bohemian life and night entertainment where the rigid norms of behavior were not observed (Pfeiffer 2014, 28). However, the whole period that was identified with technological progress, development of cities, urbanization, mass production, consumption and everything that was considered modern, ended with World War I. The domination of Post-impressionism, of the complete autonomy of painting that lead to Fauvism, Cubism, Expressionism and their derivatives was questioned and abandoned even by the main protagonists of these artistic movements. Dadaism was unexpectedly a powerful and influential response to the

Received April 2019 / Accepted May 2019

Corresponding author: Ana Milošević

Indipendant researcher, Smederevska Palanka

E-mail: anamilosevitz@gmail.com 
meaninglessness of the war as well as to the meaninglessness of the art that distanced itself from the social reality (Lewer 2016, 21-28).

The general trend of "return to order" marked the third and the fourth decade of the twentieth century all over Europe and it represented the reaction to radical formal experiments in cubism and abstraction that, as it was considered, distanced art too much from its original role. It was also the reaction to the historical avant-garde that endangered its 'raison d'etre` by erasing the line between art and life. One of the characteristics of this complex artistic process was the aspiration to renew the aesthetic principles of painting that is to reestablish its fundamental value as well as the continuity with the previous artistic tradition (Denegri 2010, 207). When discussing 1920s and 1930s French paintings, Bernard Dorival points out that the three dominant trends emerged as a response to the intellectualism of the art elite at the beginning of the century. Those trends were: a) the protest of instinct and heart personalized in the posthumous glory of the magical "Le Douanier" Rousseau and the 'naivism` of Maurice Utrillo; b) the protest of common sense through the rebirth of figurative painting that during neorealism revived long a lasting tendency towards realism, nature, man, love for the craft and distrust towards the 'new'; c) the protest against subjectivity that included different fractions of Expressionists and Surrealists (Dorival 1960).

\section{SERBS IN PARIS}

After World War I Paris became an important destination for Serbian and Yugoslav artists who wanted to become familiar with the current trends of European art. The representatives of the older generation of Serbian modernists were at the top of a long list of painters who were educated or came to the French capital for study visits. As budding or already established artists there are the following painters: Borivoje Radenković (19011905), Milan Milovanović (1902-1906), Nikola Jeremić (1907-1908, 1912 and permanently from 1915), Natalija Cvetković (1908-1909), Ana Marinković i Vidosava Kovačević. Moša Pijade (1909-1910) and Branko Popović (1909-1912). They spent time in Paris during the great glory of Cézanne, the peak of Fauvism and the beginning of Cubism. The time that Nadežda Petrović (1910-1911) spent in Paris is considered a complete emancipation of light and color (Ambrozić1957, 213). Petar Dobrović (1912-1914), Jovan Bijelić, Todor Švrakić (1913 and 1914) and many others also studied in Paris.

As early as the 1920s Paris became the place where Serbian artists encountered new ideas and learned about modernism. They went to Paris for short study trips in order to visit the important historical sites, museums, theatres, and to feel the atmosphere of the city. There were painters who received either state, or other scholarships, as well as those who had financial means or who were supported by their families. All of them would enroll in different art schools and spend there several months or semesters. Right after the end of the war, the first to study art were Miodrag Petrović (1918-1920) and Anđelija Lazarević (1920) who enrolled inÉcole des Beaux-Arts. The students from Serbia had access to many académies libres such as Académie Julian, Académie Ranson, Académie Carrière, Académie Colarossi, Académie Suisse, etc (for more information about the system of work in studios, see Macdonald 2004, 284-290). Miloš Golubović, Živorad Nastasijević and Sibe Miličić (1920), Veljko Stanojević (1920-1922), Milan Konjović (1924) also attended Académie de la Grande Chaumière. However, Académie Montparnasse 
run by the renowned painter and pedagogue André Lothe was especially attractive to the Serbian artists who desired to adopt the modernist post-Cubist syntax. During the 1930s the following painters studied at Lothe's academy: Sava Šumanović (1921 and 19251926), Milan Konjović (1924), Zora Petrović and Momčilo Stevanović (1925-1926), Stojan Aralica (1926), Milenko Šerban (1927) and many others (Ambrozić 1974, 19-28; Trifunović 2014, 134-138).

The time spent in the Parisian museums and galleries studying both old masters and modernists was an unavoidable educational segment, especially for those who felt limited by the methodologies of art schools and studios and who had chosen unconventional education. Milan Konjović remembers, "I met many of our painters copying the famous paintings... Moma Stevanović copied Giorgione. Milunović also came to copy Poussin and Dobrović and many others." (Konjović 1998, 101). If we leave out the painters educated in central European art centers that had rich public collections, Paris and its museums were the places where the majority of younger painters from Belgrade and Zagreb art schools could study the work of the old masters that before they could only see in black and white photographs in a few available publications. There were no opportunities to see the work of famous western European painters in Belgrade. The Prince Paul Museum was the only museum and it had a very modest collection at the time (Sokić 1996, 53). "Paris at that time had outstanding galleries, not only Louvre... where Matisse, Picasso, Chagall and all at their peak exhibited their work... The exhibitions would take turns and we could see the art production and learn from it about the contemporary art", Cuca Sokić pointed out in her interview (Sokić 2004). Ten years earlier, in 1926 Petar Lubarda and Mihajlo Vukotić also traveled to Paris "to see Chagall and Soutine" (Živkovic 1987, 20).

A few Serbian artists managed to live in Paris either for a long term or on several occasions trying to "make a name in the enormous city in which there are numerous exhibitions every day, and where hundreds of artists came dreaming of being noticed..." (Simeunović-Ćelić 1997, 69). Many Serbian painters lived in Parisian apartments and studios in Montparnasse, Montrouge and Malakoff: Milo Milunović (1919-1922 and 19261932), Sava Šumanović (1920-1921, 1925-1928and 1928-1930), Marko Čelebonović (1921-1926 regularly visited it while living in Saint-Tropez), Milan Konjović (1924-1932), Kosta Hakman (1926-1929), Petar Lubarda (1926-1932 and1938-1940), Stojan Aralica (1926-1933) and others. Serbian painters who were present in the art life of the French capital, moved into the bohemian circles of Montparnasse and were noticed by the critics who wrote about their work. Some of their paintings were bought by state institutions and collectors, and they received commissions(for example,Sava Šumanović painted the pillar for the newly opened restaurant "La Coupole". In: Viaud 2013, 48-67). They participated almost regularly in annual contemporary art exhibitions such as Salon d'Automne, Salon des Indépendants and Salon des Tuileries. In Parisian galleries Milunović had solo exhibitions in 1929 and 1931, Konjović in 1931, 1932 and 1937, Čelebonović 1926, 1930, 1932 and 1937. Čelebonović, Aralica, Milunović and Uzelac exhibited their work at The exhibition the four Yugoslav artists in 1931. Čelebonović, Perić, Milunović and Konjović were amongst 27 represented in 1932 at the Exhibition of Yugoslav artists who live in Paris.

During the mid 1930s another group of young Serbian painters arrived to Paris: Bora Baruh (1935-1938), Bogdan Šuput (1938-1939), Cuca Sokić (1936-1939), Peđa Milosavljević (1936-1941), Danica Antić (1938-1940), together with a painter from the previous generation,the already renowned Vasa Pomorišac (1935-1939). During those years the Association of Yugoslav artists from Paris was restored and it gathered about forty 
painters and sculptors from various generations: its president Nikola Jeremić was described as 'the old and distinguished gentleman who lived in Paris since 1907', Peđa Milosavljević was a secretary and Petar Lubarda was a treasurer (Stojković 1939, 13). The exhibitions were organized in Parisian galleries in 1937 and 1939. This generation of young painters was recognized as the 'standard-bearer' of the new spirit of intime and poetic-realistic orientation, eclectic, "anti-intellectual" and "anti-rational". They were dedicated to representing the visible world but, at the same they were convinced of the inexplicable and almost magical value of a piece of art that is simultaneously melancholic and deeply subjective (Čelebonović 1971, 25-36; Denegri 2017, 17).

\section{LJUBA IVANOVIĆ: THE OLD PARIS}

Not all Serbian painters could experience the adventure of living in the French capital. However, a short study trip was considered a kind of `initiation`. It was mandatory for all those who hoped to succeed and artistic education was not considered complete without it. Absorbing as many impressions as possible was considered to be an imperative, as well as seeing the most important sites, strolling along Parisian boulevards and the banks of Seine, resting in some of the cafes, visiting night bars and cabarets. Of course, the following activities were also included: visiting museums and exhibitions in Parisian galleries, painting several landscapes (or at least making sketches) that would be displayed for the audience in Serbia.

Ljuba Ivanović, the Belgrade Art school professor, came to Paris in 1930 for the second time (the first time he was in Paris in 1921). He was accompanied by his friend Momčilo Milošević who was an author, theatre critic and theatrologist (Paunović1976, 108-110). The fellow travelers used different media to recorded their impressions: the next year in Belgrade Milošević published the travelogue "The Letters from Paris" and Ivanović illustrated it with seven drawings with the motifs from the French capital (Milošević 1931). "The Letters from Paris" was addressed to the readers, especially to the educated ones who planned to take a similar journey, not so many descriptions of the sites of Paris, but the author's personal impressions, attitudes and opinions about life, culture and history interesting strolls and anecdotes. Equally intrigued with the past and the future, Milošević offered several possible itineraries by organizing his book into relevant chapters: Through Glory and Misery, In the Shadow of the Latin Quarter, Montmartre, On the Banks of the Seine, Under the Willow Tree of A. de Musset, Chantilly, Through Gardens and Forests; In the Homeland of Marquise de Sevigne; The Soul of Paris; Above the Roofs of Paris. He invited the readers to "Join me for a walk through this city of beauty and inconceivable secrets" (Milošević 1931, 26). That is the Paris that is presented by Ljuba Ivanović in his drawings. Commenting on Ivanović's work, Vanja Kraut points out that the Paris that is recorded is "not the recognizable Paris of cabarets, busy boulevards, noisy dances, horse races and train stations but the Paris of remote districts, dilapidated buildings, quiet neighborhoods with retail shops time that stopped", made with the same fabric as in Eugène Atget's photographs. Ivanović drew the banks of the Seine Île de la Cité, the view on Île Saint-Louis form Pont Marie and Pont de la Tournelle, narrow streets in the vicinity of Saint-Gervais-et-Saint-Protais church, Hôtel de Lemoignon, Notre-Dame de Lorette, fragments of Boulevard de Sebastopol, all the way to Montmartre (busy Place Blanche and 
Boulevard Clichy), Passage de la Petite Boucherie (Fig. 1) ${ }^{1}$ in the vicinity of St Germainde-Pres, and several unidentified locations known only by the common name "Paris" (Fig. 2) ${ }^{2}$. In these drawings Ivanović "showed more respect to time than life, past than a man" (Kraut 1976, 39) and he achieved that by evoking a kind of poetic mood by the play of light and shadow, refined materialization of jagged facade surfaces, decrepit buildings and modern multi-storey houses, dynamics of their roofs against the Paris sky, shady narrow streets." In 1932 the portfolio "The Old Paris" was published in 29 copies. It represented the collection of six original woodcuts and was based on the drawings from Paris (Medaković 1969, 10-11; Kraut 1976, 41). For his drawings and etchings with the motifs of Paris, Ivanović was awarded the Chevalier Legion of Honour Medal by the president of the Republic of France in 1933 (Kraut 1976, 41; Ratković 2008, 9).

\section{Mihailo S. Petrov: The ThreE `PARIS`}

A reason to come to Paris might have been a visit to one of the world exhibitions that represented main international cultural events. The examples were the International Exhibition of Modern Decorative and Industrial Arts (Exposition internationale des arts décoratifs et industriels modernes) in 1925 and the International Exposition of Art and Technology in Modern Life (Exposition Internationale des Arts et Techniques dans la Vie Moderne) in 1937. The World Exhibition in 1925 was visited, amongst others, by Mihailo S. Petrov (Živković 1979, 15), Stojan Aralica (Jaksic, 2016, 15) and Bogdan Šuput in 1937. They came together with a group of The Matica Srpska scholarship students (Jovanovic 1984, 43).

Mihailo S. Petrov arrived to Paris in 1937 for the second time, perhaps to visit the International Exposition that took place from April to October. There are neither written records nor author's oral testimonies about the trip. It is not known, for example, when he arrived there, how long or where he stayed. However, Petrov's stay in Paris is documented by several paintings with Parisian motifs. They are Paris, ${ }^{3}$ Notre-Dame - Paris ${ }^{4}$ and A Street in Paris. ${ }^{5}$

\subsection{A Room with a View I}

The painting Notre-Dame - Paris (Fig. 3) represents the view of Île de la Cité with the Notre-Dame Cathedral and Pont au Double, and the bridges Pont de l'Archevêché and Pont de la Tournelle in the distance. Petrov painted the cityscape from the left bank of the Seine from the Quai Saint-Michel, more precisely from the window of the nearby Le Notre-Dame Saint-Michel Hotel. Recognizing the motif from the painting Paris (Fig. 4) was not an easy task. The broad street with only a few cars, buildings and the part of a square look very "Parisian" and could be found anywhere in the French capital. The solution of this puzzle is very simple: having painted Notre-Dame, Petrov moved the scene slightly to the right, along the Quai de Montebello and the street Rue de la Bucherie, over the green areas of the

\footnotetext{
${ }^{1}$ Old Paris 3 (Passage de la Petite boucherie), 1930, pencil on paper, $36 \times 26 \mathrm{~cm}$, National Library of Serbia,GR 867.

${ }^{2}$ Paris, 1930, pencil on paper, 37x 25,3 cm, Pavle Beljanski Memorial Collection, inv. no. SZPB 27.

${ }^{3}$ Paris, 1937, oil on canvas, 32 x 40,5 cm, National Museum in Smederevska Palanka, inv. no. 13.

${ }^{4}$ Notre-Dame-Paris, 1937, oil on canvas, 73 x $60 \mathrm{~cm}$, National Museum in Smederevska Palanka, inv. no. 408.

${ }^{5}$ Street in Paris, 1937, oil on canvas, 73x60, National Museum, Belgrade, inv. no. 378.
} 
René Viviani square, all the way to the multi-store building in Rue Lagrange. The wide panorama of Paris cityscape that seen from his room (Fig. 5) was divided into two parts that follow spatially but could be also seen as two separate paintings.

The first painting Notre-Dame - Paris could be qualified as a postcard of the French capital. Mihailo S. Petrov, like many others before him, painted one of the most recognizable symbols of the city - The Notre-Dame Cathedral that represents the topos of French historical and cultural memory. The series of paintings by Henri Matisse and Albert Marque from the beginning of the twentieth century is among the most famous representations of the cathedral. They were painted from the two windows facing north and the Seine in the apartment/studio on 19 Quai Saint-Michel where the two painters and friends used to live and work. In 1909 Maurice Utrillo painted the facade of Notre-Dame and in 1920s and 1930 she painted the scene again.

Although the Facade of Notre-Dame and Notre-Dame painted by Nadežde Petrović in 1911 "do not have ideological-patriotic substance like the pieces created in Serbia and they are the most important pictorial research and color experiment" (Merenik 2006, 81), for Serbian painters the idealized historical landscapes represented neither neutral motifs suitable for solving formal problems, nor did they have the role of documenting the past no matter how magnificent the past was. They represented a mode of distancing themselves from the social reality with all its conflicts and contradictions and an escape into "safe" romantically understood art sphere. Some other Serbian painters who lived in Paris also painted Notre-Dame in 1930s: Peđa Milosavljević in 1938 and Bogdan Šuput in 1939. Milosavljević recorded several other sites of Paris - A View of Louvre in 1937 in the vicinity of Île de la Cité, on the left bank of Seine - Musée de Cluny in 1938, the church of SaintSéverin in 1939 (Protić 1978, 13), while Šuput painted Opera in 1938 (Jovanovic 1984, 54).

Mihailo S. Petrov was a historian of art and contemporary art expert. He was certainly familiar with the Notre-Dame series painted by the famous Fauvists. When choosing the hotel for his stay he might have had in mind the two artists who used to live in a studio in the neighbourhood, that was only one block down the Seine. Petrov brought back to Belgrade the painting Notre-Dame-Paris and modeled another painting after it although it was bigger in size and had a different color scheme ${ }^{6}$. Cold dark blue colors were replaced with warmer brown shade, and metallic grey Paris was replaced by "patinated" museumlike brown representation.

\subsection{A Room with a View II}

In his other painting Paris, Mihailo S. Petrov pays respects to Paris as a modern, busy metropolis, the international center of art and education by recording the fringes of the Latin Quarter. The wide boulevards, avenues, squares and streets, usually seen panoramically from a window of the upper floor apartments intrigued painters since Impressionism. Monet's Boulevard des Capucines (1873), Gustave Caillebotte's Paris, Rainy Day (1877) and Pissarro's many versions of Boulevard Montmartre (1897), or Avenue de l'Opera (1898) record the impressions and movements of the metropolis through cityscapes. These "painters of the modern life" were careful observers (Bodler 2013 , 12) who filled the space of the urban scene in their paintings with parading bourgeois - well dressed women and men (flaneurs, boulevardier) who reflect the

\footnotetext{
${ }^{6}$ Notre-Dame, 1937, oil on canvas, 100x126,5, Museum of Contemporary Art, Belgrade, inv. no
} 
changed nature of the city. "The story" takes place in the pronounced geometrically organized public space consisting of carefully drawn buildings, trees and streets. By using the sharp brush strokes and by an Impressionist use of colors they evoked the fast pace of modern life as a central aspect of urban society at the end of the 19th century. The Impressionists adopted the elevated observation point from the Japanese 19th century prints, especially from the series One Hundred Famous Views of Edo by Utagawa Hiroshige. Influenced by Japanese scrolls (kakemono, kakejiku), Edouard Vuillard painted the diptych La Place Vintimille and four panels named Streets of Paris. Both pieces were painted in 1908 . The city scenes were presented from the narrow elevated perspective, they were elongated and very similar to ribbons (Metilić 2017, 107). The paintings of a bustling city that vibrates in the rhythm of people and vehicles were the favorite themes of Pierre Bonnard who made a series of 12 lithographs Some Aspects of Paris Life (1899) commissioned by Ambroise Vollard (Ives 1989, 121). Bonnard treats the spaces of the Montmartre - Boulevard Clichy, Place Pigalle, Place Blanche in his paintings as architectural coulisse for the citizens of Paris and their ordinary lives.

Many of the Serbian artists who lived in Paris in the 1920s and the 1930s chose to paint ordinary scenes instead of bustling streets of Paris and wide boulevards with modern buildings. For example, the suburb of Malakoff was painted by Kosta Hakman in 1926 and 1928, Stojan Aralica in 1929, Petar Lubarda in 1932 (Stojanović 1989, 12; Jakšić 2016, 15; Kvas 2017, 28), while in 1930 Lubarda records small segments from the immediate surroundings such as shop windows or cafes that could not provide information about their exact location in his paintings Blue Saloon - Café and Blue Shop Window (Kvas 2017, 33). In 1928 Kosta Hakman recorded a city space by painting one of the landmarks of Paris, the bridge Pont Neuf. He introduced into the scene a group of people and cars that go over the bridge. Although it could be said that they illustrate the bustle of the metropolis, those dark silhouettes counterbalance the block of closely positioned multi-store buildings painted in the right half of the painting in the massive architectonic of the bridge that is the center of the composition (Stojanovic 1989, 12). Eight years later, during his second visit to Paris, Hakman painted a new and bright picture of the French metropolis through the open window of the studio entering the privileged artistic space (Метлић 2017, 121). Bogdan Šuput was also amongst "our artists in the attics of Paris". He painted a part of Boulevard Saint-Michel, by looking at it through the window of his room (although the frame is missing this time) in Hotel de Suez at the very top of the building (Jovanović1984, 50). He positioned the boulevard diagonally, with the domineering multi-store buildings on the corner of Rue Racine and Rue de l'École Médicine and with rows of green trees that lead the spectator's eye up, towards the Seine, all the way to the center of the perspective in the painting that is placed in the outline of the Sainte Chapelle's spire.

Painting Quai de Montebello by looking at it from the window of his hotel room, Mihailo S. Petrov shows that this normally very busy road is almost empty with only a couple of cars represented as dots that merge into grey. The city space devoid of human presence is always a testimony of transience, as a rule followed by melancholic atmosphere of a rainy day in autumn. With the choice of motifs and their representation, Petrov reveals his own identity and position as a man and as a painter. By painting the tourist attraction Notre-Dame he shows himself as a provincial painter from a small country fascinated by the history of France and the symbols of its power and continuity. 
With his other paining Paris, Petrov positions himself in the wide international cultural community on the left bank of Seine that gravitates towards the Sorbonne with its picturesque bookshops, cafes and cheap hotels.

\section{3. "The Holy ground" of art}

The painting A Street in Paris belongs to the series created during Mihailo S. Petrov's second stay in Paris (Fig. 6). According to the intimistic and poetic-realistic position, the painter is presented here as a chronicler of ordinary, everyday, non-aesthetic reality given through the prism of personal impression. Although the cityscape appears to be ordinary, it offers "the images of neglected side streets that only differ by its décor and pavement from the already mentioned outskirts of Belgrade" (Vićentijević 2012, 53). Petrov used the painting to record the urban segment of a Paris quarter. However, the choice of the "scene" is far from random. Due to one cityscape painted by Vasa Pomorišac in 1937 that shows the same street corner, the same building and shoe shop with the sign "Bottier", we know that it is the part of Montparnasse (the painting with the name On Montparnasse, catalogue number 64, in Slijepčević 1986). The two painters knew each other well, they even exhibited their work together. It could be assumed that during his stay in Paris, Mihailo S. Petrov visited his colleague and friend in the studio on 161 Boulevard Montparnasse, and then both of them painted this picturesque motif. Named "the tower of Babylon" or "the navel of the world" (Viaud 2013, 51-53), from the beginning of the twentieth century and especially after World War I, Montparnasse became the symbol of personal and artistic freedom where everyone could find a place and expression (Jovanov, 2010, 5). A tourist, an intellectual and a painter, Mihailo S. Petrov chose to paint the "third" Paris - Montparnasse, the one that was the most important for the artists.

\section{SVETOLIK LUKIĆ: PARIS “OF InSTINCT AND HEART”}

As a mature painter, Svetolik Lukić received the scholarship from the French government in 1939. He traveled to Paris and enrolled in the famous Académie Ranson. It appears that whichever art school he might have attended it would have made no difference because there was "only one true and real art school called Paris" (Kolarić 1983, 4). Despite the fact that he lived in Montparnasse like many other Serbian painters during their stay in Paris, Lukić visited Montmartre that even by the end of 1940 s retained its status of destination not to be missed in the itinerary of every serious pilgrimartist. Montmartre acquired its recognizable reputation by being simultaneously on the margin and in the center, a village and a city with its special mixture of rural nature, uninhibited entertainment and cheap apartments. If Paris was called "the capital of art", Montmartre was "the capital of pleasure" and dissidence (Parker 2014, 289). Beginning with World War I a growing number of artists moved to Montparnasse. Montmartre lost something of its former reputation although it remained the center of entertainment.

In his painting La Place du Tèrtre (Fig. 7) ${ }^{7}$, Svetolik Lukić painted this famous square during winter months in 1940. The usual absence of bustle that we would see today, a small number of passersby, bare tree branches and empty benches direct the attention towards the vivid facades, awning shades of cafes and shop signs create characteristic and a very

${ }^{7}$ La Place du Tèrtre, 1940, oil on canvas, 38,5 x 46,5 cm, National Museum in Smederevska Palanka, inv. no. 20. 
personal "Utrillo-like" portrait of Montmartre. ${ }^{8}$ In the similar vein Lukić painted another piece during his stay in Paris, St. Paul's Square in Paris. ${ }^{9}$ If Miodrag Kolarić describes Lukić's paintings as sketchy before he left for Paris (Kolarić 1983, 4), then "painting by instinct and heart" (Dorival 1960, 16) that appeared occasionally in his earlier works would prevail as liberated color and pure painting substance under suggestive naivism of Maurice Utrillo. Although Lukić later visited Paris again and painted its squares and streets, never again did he repeat directness and colorfulness of his first "postcards from Paris".

\section{CONCLUSION}

Coming to Paris, seeing all its wonders, absorbing the atmosphere, becoming richer by experiencing its history and culture, becoming sanctified with its art was the mission of all pilgrims regardless of the part of the world they came from. Serbian artists who arrived to the French capital were not an exception. Depending on the length of their stay, financial means and expectations, inclinations and desires, they would choose different artistic itineraries that could be interpreted as different faces of Paris: the old Paris that disappears, the secret, picturesque and romantic, the historical Paris with famous landmarks, bohemian Paris with cafes and nightclubs, the Paris of museums, galleries and artistic conversations; Paris of modern boulevards and Parisians in hurry; the Paris of small squares, picturesque little shops, the ordinary Paris with its intimate spaces, run-down outskirts with the shabby houses and muddy streets that resembled those in Belgrade. Those painters chose the face of Paris that mostly corresponded to the image they already had about Paris, or the scenes that represented their own identity. Similarly, they would take from the contemporary French painting only what could be incorporated in the existing model that determined the relationship between the objective and the artistic, what was seen and what was represented.

The time our artists spent in Paris, especially their short stays, could be compared to pilgrimages. The pilgrimage included preparations for the journey, finding the accommodation, planning the visits of sites of Paris, weather independent or guided visits, making sketches, drawings and paintings in situ. Similar to any other pilgrimage, souvenirs play an important role in this "artistic pilgrimage". They testify that the journey took place and they retain their "magic qualities"..."of a holy place" where they come from. Ljubomir Ivanović illustrated the book of his friend and fellow traveler with his original drawings and made series of woodcuts published in the portfolio "The Old Paris". It is not known whether Mihailo S. Petrov and Svetolik Lukić exhibited their motifs from Paris during group exhibitions on their return to Belgrade or if they kept them as valuable memorabilia.

\section{REFERENCES}

Ambrozić, K., (1957), Pariski period Nadežde Petrović. Peristil, Vol. 2 No. 1, Društvo povjesničara umjetnosti Hrvatske, Zagreb, str. 211-214.

Амброзић, К., (1974), Андре Лот и његови југословенски ученици/André Lhote et ses élèves yougoslaves, каталог изложбе, Народни музеј, Београд.

Argan, Đ. K. \&Oliva, A. B., (2005), Moderna umetnost 1770-1970-2000, II. Clio, Beograd.

\footnotetext{
${ }^{8}$ There is a big similarity to the lithograph of Maurice Utrillofrom 1924 that deal with the same topic.

${ }^{9}$ The Place Saint-Paul in Paris, 1939/40, oil on canvas, 54 x $65 \mathrm{~cm}$, Museum of Contemporary Art, Belgrade, inv. no. MSU/I 1352.
} 
Blanuša, M. \& Ratković, Ž., (2008), Grad, Hronike urbanog prostora, katalog izložbe. Galerija Matice srpske, Muzej savremene umetnosti, Novi Sad-Beograd.

Bodler, Š., (2013), Slikar modernog života, Službeni glasnik, Beograd.

Čelebonović, A., (1971), Težnja izvornosti u srpskom slikarstvu između dva rata, In: Četvrta decenija: ekspresionizam boje, poetski realizam, katalog izložbe, Muzej savremene umetnosti, Beograd, str. 25-36.

Denegri, J., (2010), "Povratak redu”. In: M. Šuvaković (ed.). Istorija umetnosti u Srbiji XX vek: Radikalne umetnicke prakse, I, Orion art, Beograd, str. 207-215.

Denegri, J., (2017), "Marko Čelebonović i paradigma umetnika kao progresivnog građanina”. In: Grupa autora. Marko Čelebonović. Kragujevac: Galerija Rima, str.15-39.

Dorival, B., (1960), Savremeno francusko slikarstvo, III, Svjetlost, Sarajevo.

Јакшић, Ј., (2016), Павле Бељански пријатељ уметника: Стојан Аралица, каталог изложбе, Спомен збирка Павла Бељанског, Нови Сад.

Јовановић, В., (1984), Сликар Богдан Шупут, 1914-1942., Спомен збирка Павла Бељанског, Нови Сад.

Коларић, М., (1983), Светолик Лукић, каталог изложбе, Народни музеј, Београд.

Јованов, Ј., (2010), Артисти и модели: Сава Шумановић и краљица Монпарнаса, каталог изложбе, Галерија слика „Сава Шумановић“, Шид.

Краут, В., (1976), Љубомир Ивановић, САНУ, Београд.

Краут, В., (2009), „Љубомир - Љуба Ивановић“, У: Ј. Јованов (ур.), Спомен збирка Павла Бељанског, Спомен збирка Павла Бељанског, Нови Сад, стр.104.

Квас, М., (2017), „Лубарда и Бељански: портрет пријатеља“, У: Петар Лубарда 1907-1974-2017, каталог изложбе, Спомен збирка Павла Бељанског, Нови Сад, стр. 28-47.

Коњовић, М., (1998), “Копирање, самоћа”,У: М. Јосић Вишњић, Столеће Милана Коњовића (1898-1998), Галерија „Милан Коњовић“, Књижевна фабрика „МЈВ и деца“, Сомбор, стр. 101

Lewer, D., (2016), "Dada’s Genesis: Zurich", In: D. Hopkins (ed.), A Companion to Dada and Surrealism, WileyBlackwell, Oxford.

Медаковић, Д., (1969), Љубомир Ивановић. Просвета, Београд.

Merenik, L., (2006), Nadežda Petrović: projekat i sudbina. Topy \& Vojnoizdavački zavod, Beograd.

Метлић, Д., (2017), Слике пролазног света: односи франиуског и српског интимизма, Галерија Матице српске, Нови Сад

Милошевић, М., (1931), Писма из Париза:оригинални иртежи љ. Ивановића, Издавачка књижарница Геце Кона, Београд.

Parker,McD. R.,(2014), "Picasso and Montmartre: Fertile Grounds for Artistic Creation", In: I. Pfeiffer, M. Hollein (ed.), Esprit, Monmartre, Bohemian Life in Paris around 1900, Schirn Kunsthalle Frankfurt\&Hirmer, Frankfurt, pp. 289-294.

Пауновић, С., (1976), “Момчило Милошевић”, Театрон бр. 5: 108-110.

Pfeiffer, I., (2014), "Esprit, Monmartre, Bohème and a View of an Unfamiliar Paris",In: I. Pfeiffer, M. Hollein (ed.), Esprit, Monmartre, Bohemian Life in Paris around 1900, Schirn Kunsthalle Frankfurt\&Hirmer, Frankfurt: 25-36.

Protić, M. B., (1978), Predrag-Peđa Milosavljević, retrospektivna izložba 1928-1978., MSU, Beograd.

Ratković, Ž., (2008), Ljubomir Ivanović: fragmenti zaustavljenog vremena, crteži i grafike iz Muzeja savremene umetnosti u Beogradu, katalog izložbe, Muzej savremene umetnosti, Beograd.

Симеуновић-Ћелић, И., (1997), Мило Милуновић: непресушна тежюа суштини сликарске материје и боје. САНУ, Београд; ЦАНУ, Подгорица.

Slijepčević, Lj., (1986), Vasa Pomorišac 1893-1961, katalog izložbe, MSU, Beograd.

Sokić, Lj., (1996), "Otkriće neke smirenosti, neke senzibilne racionalnosti”, Intervju vodila I. S. Čelić, Likovne sveske, 9, Zavod za udžbenike i nastavna sredstva, Fakultet umetnosti, Beograd.

Sokić, Lj., (2004), "Boje Pariza", Intervju vodio M. Šarac, Novosti, 1. decembar 2004. http://www.novosti.rs/ dodatni_sadrzaj/clanci.119.html:276844-Boje-Pariza 15.4.2019.

Stojanović, Lj., (1989), Kosta Hakman 1899-1961, retrospektivna izložba, MSU, Beograd.

Стојковић, Љ., (1939), Наши уметници на париским мансардама: заједничка изложба свих наших уметника у Паризу, Правда, 5.март 1939, стр. 13.

Трифуновић. Л., (2014), Српско сликарство 1900-1950, СКЗ, Београд.

Viaud, G., (2013), „Сава Шумановић у ресторану La Coupole на Монпарнасу“, У: Т. Палковљевић (ур.), Сава Шумановић и тајна под Куполом/ Sava Šumanović et le secret de la Coupole, Галерија Матице српске, Нови Сад, стр. 48-67.

Вићентић, Т., (2012), Михаило Петров: уметност на поклон, Народни музеј, Аранђеловац.

Živković, S., (1979), "Slikarstvo Mihaila Petrova", In: (grupa autora), Mihailo S. Petrov, Umetnički paviljon Cvijeta Zuzorić, Beograd, str. 11-25.

Живковић, С., (1987), Уметничка школа у Београду 1919-1939, Галерија САНУ, Народни музеј у Београду, МСУ, Београд. 


\section{USPOMENE IZ PARIZA: TRI HODOČAŠĆA SRPSKIH UMETNIKA 30-IH GODINA 20. VEKA}

Tridesetih godina dvadesetog veka veliki broj srpskih slikara dolazi u Pariz da se upozna sa savremenim tendencijama u umetnosti, muzejima i galerijama. Na Monparnasu i u Malakofu se formiraju male kolonije srpsko/jugoslovenskih umetnika koji se aktivno uključuju u tekuću produkciju i izložbenu praksu ali i umetničke krugove francuske prestonice. Oni koji nisu mogli da priušte da studiraju ili žive u Parizu dolazili su na kraće ,,intenzivnije“ studijske boravke koji su imali karakter umetničkog hodočašća. Za relativno kratko vreme trebalo je videti sva čuda, obići znamenitosti, upiti atmosferu, istoriju i kulturu francuske prestonice, a prikupljene utiske poneti sa sobom kući na crtežima i slikama. Od mnogih lica Pariza Ljubomir Ivanović, Mihailo S. Petrov $i$ Svetolik Lukić biraju ona za koja smatraju da najbolje reprezentuju kako identitet grada tako $i$ njihov umetnički identitet.

Ključne reči: Pariz 30-ih godina 20. veka, Ljubomir Ivanović, Mihailo S. Petrov, Svetolik Lukić, umetničko hodočašće.

LIST OF ILLUSTRATIONS

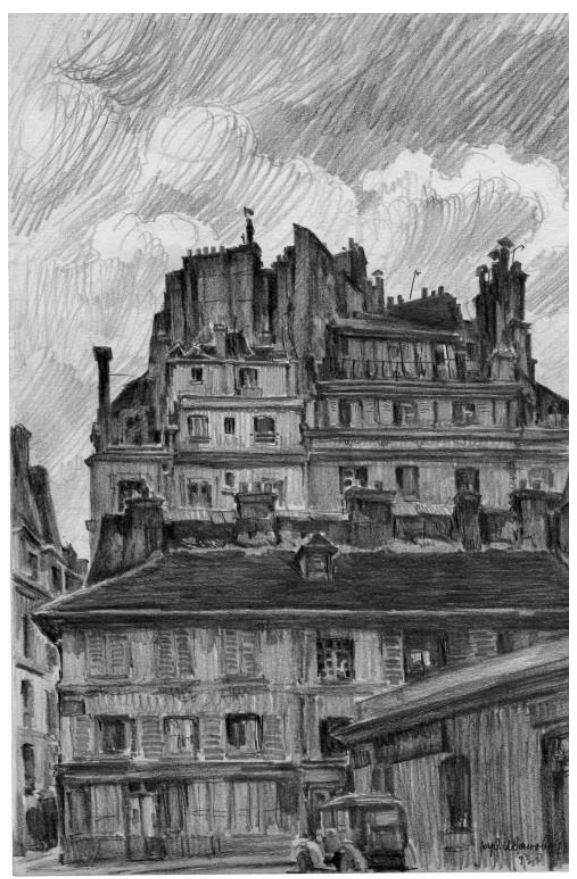

Fig. 1 Old Paris 3 (Passage de la Petite boucherie), 1930, pencil on paper, $36 \times 26 \mathrm{~cm}$, National Library of Serbia 


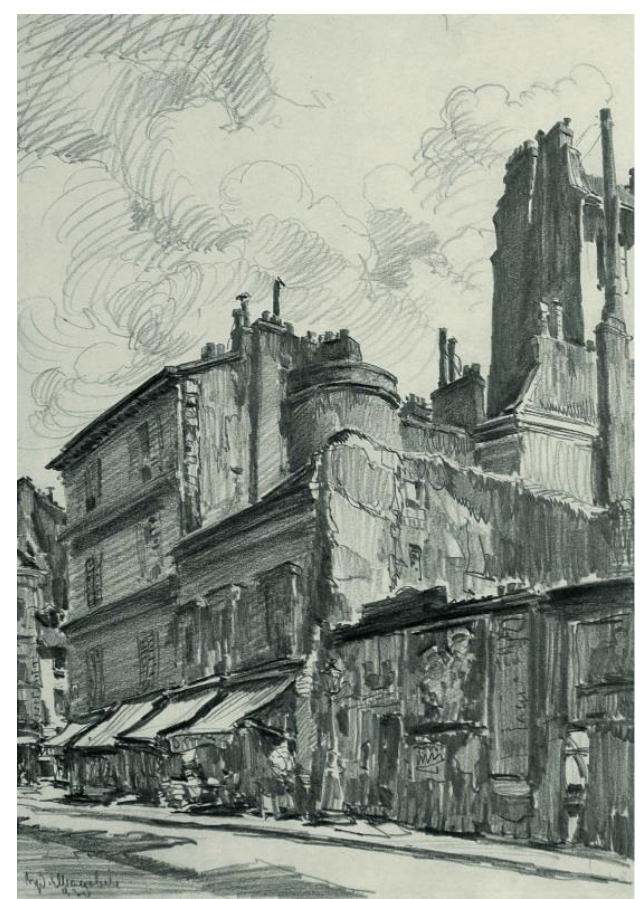

Fig. 2 Paris, 1930, pencil on paper, 37 x 25,3 cm, Pavle Beljanski Memorial Collection

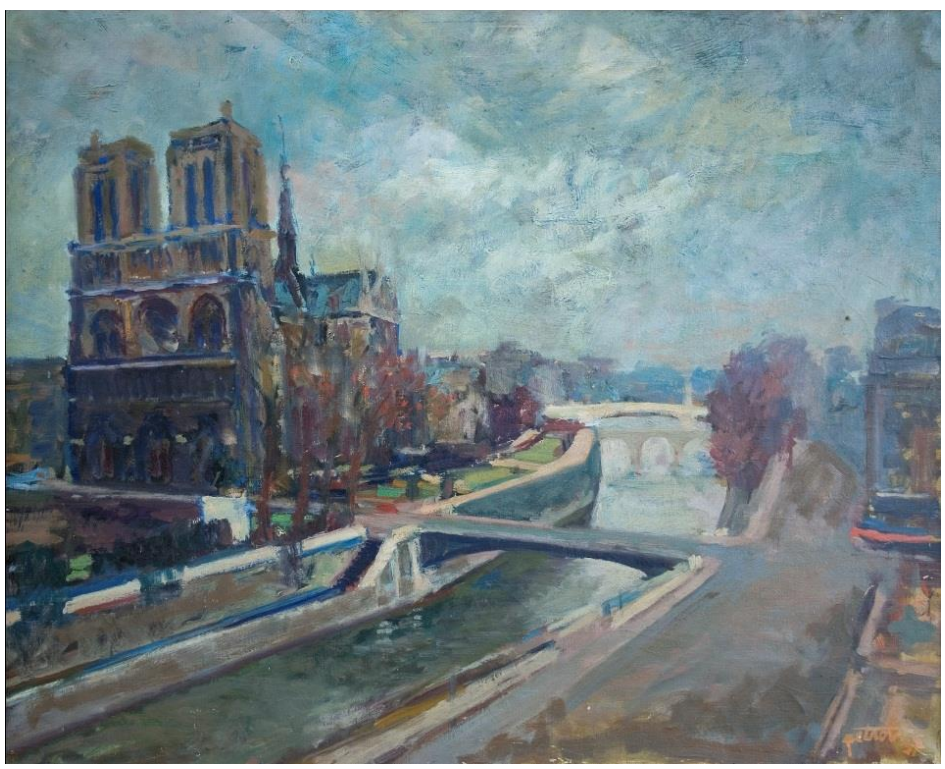

Fig. 3 Notre-Dame-Paris, 1937, oil on canvas, 73 x $60 \mathrm{~cm}$, National Museum in Smederevska Palanka 


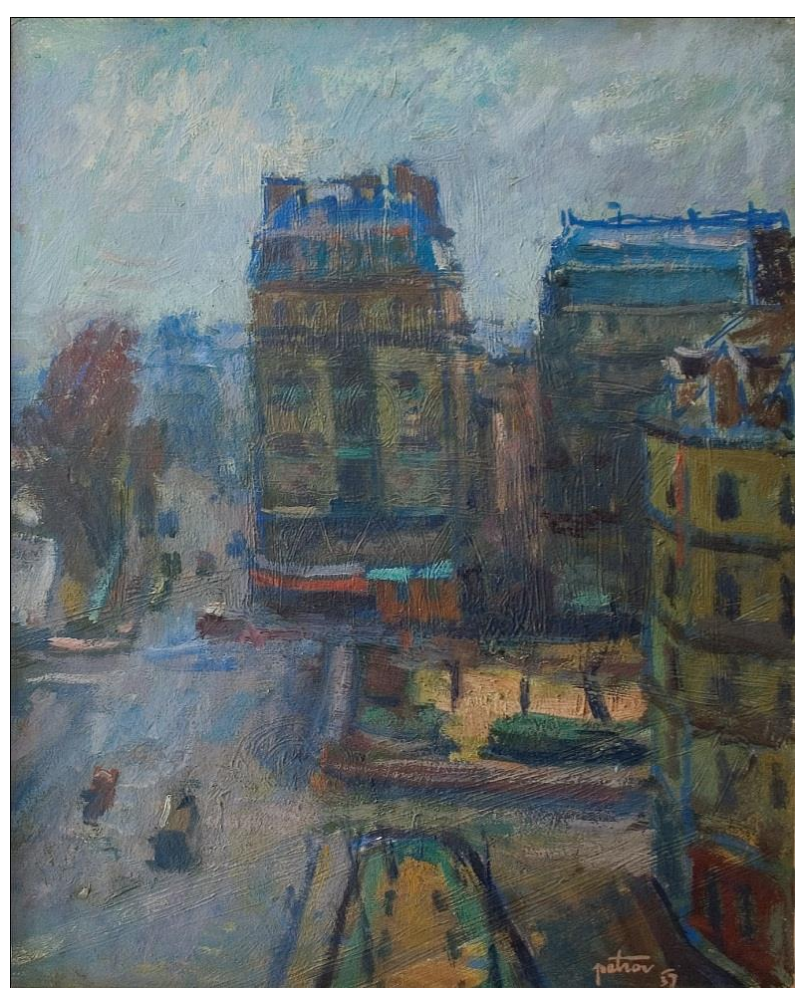

Fig. 4 Paris, 1937, oil on canvas, 32 x 40,5 cm, National Museum in Smederevska Palanka

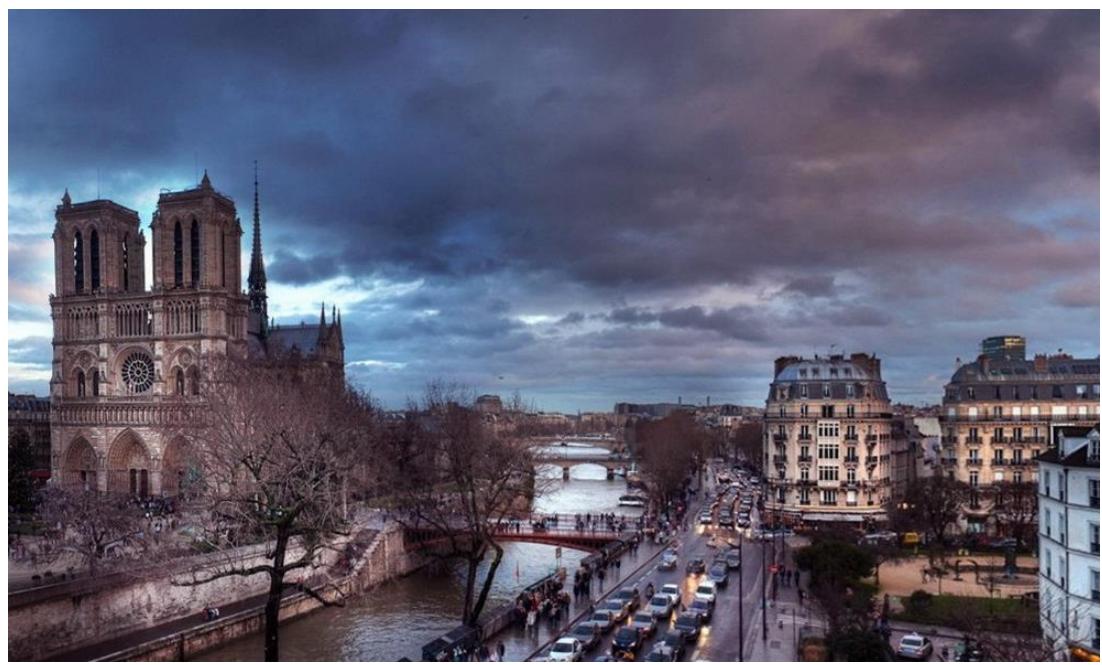

Fig. 5View from the Hotel Le Notre Dame Saint Michel, http://www.hotelnotredameparis.com/gallery.htm 


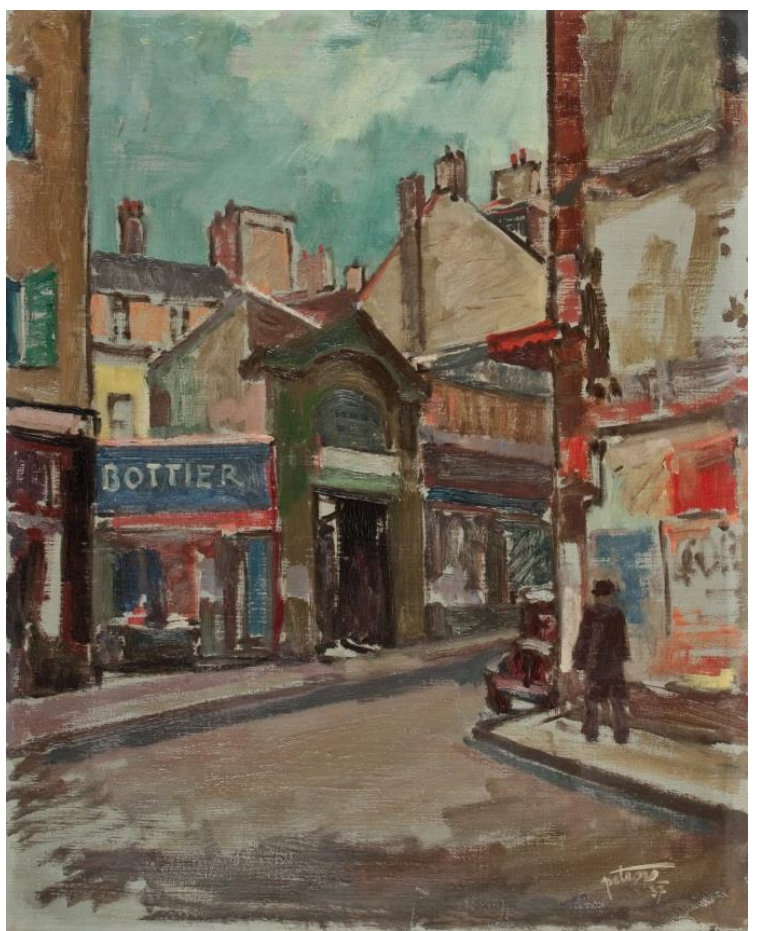

Fig. 6 Street in Paris, 1937, oil on canvas, 73x60 cm, National Museum, Belgrade

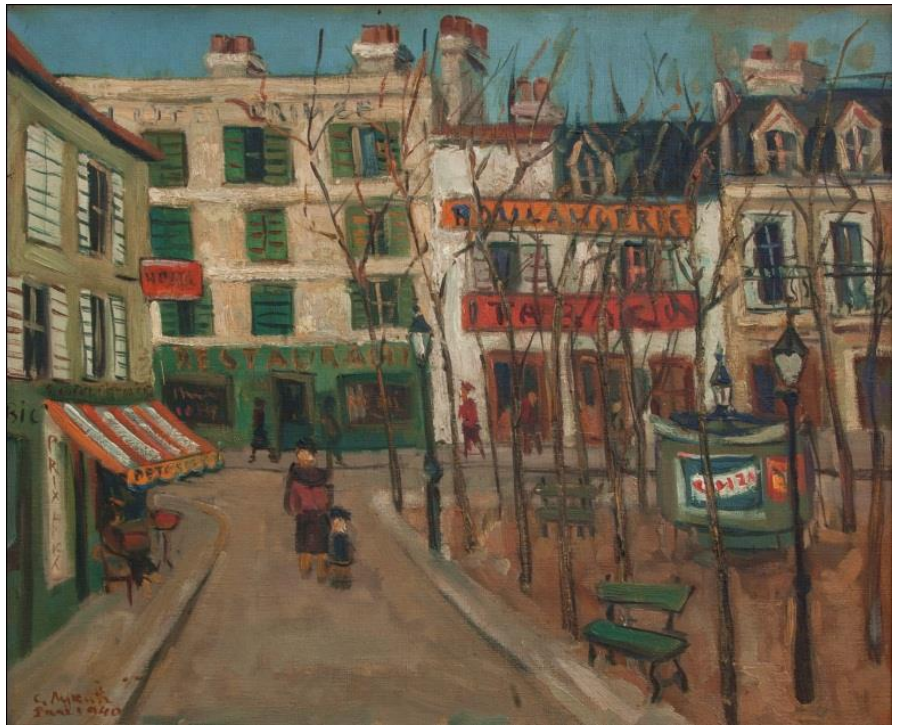

Fig. 7 La Place du Tèrtre, 1940, oil on canvas, 38,5 x 46,5 cm, National Museum in Smederevska Palanka 